\title{
Research Paper An assessment of knowledge level of farm women/rural girls related to preservation of fruits and vegetables
}

\author{
口 Rajinder Kaur Sidhu
}

Correspondence to :

Rajinder Kaur Sidhu Krishi Vigyan Kendra, Mansa (Punjab) India Email : sidhurajinder3@ gmail.com

Paper History :

Received : 03.12.2018;

Revised : 30.01.2019;

Accepted : 11.02 .2019
ABSTRACT : The present study was conducted on an assessment of knowledge level of farm women/ rural girls related to preservation of fruits and vegetables in Mansa district. Three training courses were organised on preservation of fruits and vegetables during 2016 for rural women and rural girls at KVK Mansa. In this training course 48 farm women/ rural girls had participated. These girls women belong to various villages of Mansa district. It was observed that all the trainees were receptive to the skill imparted in preservation and all of them showed high knowledge score. After getting the training the trainees were made aware of every aspect of preservation. Majority of the participants gained knowledge about every aspect of preservation of fruits and vegetables like amount of sugar for preparing jam, murabba and squashes, kind of preservatives used in processing of fruits and vegetables, skill about making squashes, syrups, chutney, tomato sauce and jam and type of containers for storing pickles and jam. awareness regarding selection of fruits and vegetables, amount of salt for preparing pickles, hygiene practices used in preparing pickles and chutneys and cleanliness aspects related to preservation. They were satisfied and ready to prepare jam, murraba pickles, chuttenys and squashes at household level and preserve the seasonal fruits and vegetables throughout the year for their family.

KEY WORDS : Knowledge level, Women, Rural, Girls related to preservation, Fruits, Vegetables

How To Cite This PAper : Sidhu, Rajinder Kaur (2019). An assessment of knowledge level of farm women/ rural girls related to preservation of fruits and vegetables. Internat. Res. J. Agric. Eco. \& Stat., 10 (1) : 80-83, DOI : 10.15740/HAS/IRJAES/10.1/80-83. Copyright@ 2019: Hind Agri-Horticultural Society. 